\title{
Effect of age and body weight on carcass traits and meat composition of rabbits
}

\author{
Szilvia Metzger'1, Meinrad Odermatt², András Szabó', István Radnai', Edit Biró-Németh', \\ István Nagy' and Zsolt Szendrö
}

${ }^{1}$ Faculty of Animal Science, University of Kaposvár, Kaposvár, Hungary, ${ }^{2}$ Olivia Ltd., Lajosmizse, Hungary

\begin{abstract}
A total of 238 Pannon White growing rabbits were slaughtered at 74,84 and 94 days of age, at an average body weight of $2.53,2.84$ and $3.15 \mathrm{~kg}$, respectively. Within each age group five body weight categories were formed in such a way that the weight difference between two neighbouring groups was equally $0.3 \mathrm{~kg}$. The design of the experiment permitted the separate examination of the effects exerted by age and body weight on carcass traits and on meat chemical composition of the left hind leg (HL) and that of $m$. Longissimus dorsi (MLD). Dressing out percentage significantly increased with the increase of age in all body weight categories, as well as with the increase of body weight. The effect of age on the ratio of the fore part of the carcass depended on the body weight: significant difference was found in lower body weight categories. The ratio of the intermediate part of the carcass was not affected by age but it increased in rabbits of higher body weight. The ratio of the hind part of the carcass increased in older animals, while it decreased in rabbits of higher body weight, and this decrease was higher in older rabbits. The ratio of the perirenal fat to reference carcass significantly decreased with age in all body weight categories, but it significantly increased in rabbits of higher body weight. With the advancement of age the moisture content of the HL increased, while that of the MLD did not change. With the increase of body weight, moisture content decreased in both the HL and in the MLD. The fat content of both HL and MLD decreased in older animals, while it increased in rabbits of higher body weight.
\end{abstract}

Keywords: rabbits, Pannon white, age, body weight, carcass traits, meat composition

\section{Zusammenfassung}

\section{Einfluss von Alter und Körpergewicht auf die Schlachkörpermerkmale und Fleischzusammensetzung von Kaninchen}

Insgesamt 238 Pannon White Kaninchen wurden am 74., 84. und 94. Tag geschlachtet. Das entsprechende Körpergewicht betrug 2,53, 2,84 und 3,15 kg. Innerhalb jeder Altersgruppe wurden fünf Gewichtsklassen gebildet bei denen die Differenz zwischen zwei benachbarten Gruppen $0,3 \mathrm{~kg}$ betrug. Untersucht wurden die Wirkungen von Alter und Körpergewicht auf Schlachtkörpermerkmale, chemische Fleischzusammensetzung der linken Keule ( $\mathrm{HL}$ ) und M. longissimus dorsi (MLD). Die Schlachtausbeute stieg in allen Gewichtsklassen mit zunehmendem Alter und zunehmendem Körpergewicht signifikant an. 
In den unteren Gewichtsklassen wird der Alterseffekt auf den Schlachtkörperwert des Vorderteils vom Körpergewicht beeinflusst. Dies ist beim Mittelteil nicht der Fall, dafür erhöhte sich der Wert bei Kaninchen mit höherem Körpergewicht. Der Wert beim Hinterteil erhöhte sich bei älteren Tieren, während er bei Tieren mit höherem Gewicht sank. Der Nierenfettanteil sank mit steigendem Alter in allen Gewichtsklassen, erhöhte sich signifikant bei Kaninchen mit höherem Gewicht. Mit fortschreitendem Alter erhöhte sich der Wassergehalt in der Keule, während der im MLD unverändert blieb. Der Fettgehalt von Keule und MLD sank bei älteren Tieren, während er bei Kaninchen mit höherem Körpergewicht stieg.

Schlüsselwörter: Kaninchen, Pannon white, Alter, Körpergewicht, Schlachtkörpermerkmale, Fleischzusammensetzung

\section{Introduction}

The carcass traits and meat composition of rabbits of different age or body weight have been studied by several authors. Some of the results are summarised in the review of Dalle Zotte (2002). In those studies the heavier rabbits were usually older and vice versa, the older rabbits had higher body weight. Therefore, it could not be determined whether the observed changes were caused by the age or the body weight. In some experiments the dressing out percentage of rabbits slaughtered at the same age but at different body weights was compared (Szendrö 1989, Grashorn et al. 1996, Petracci et al. 1999, Gondret et al. 2005). However, studies allowing separate examination of the effect exerted by age and body weight, i.e. in which rabbits of different age were slaughtered at the same body weight or rabbits of the same age at different body weights, have been scarce (Roiron et al. 1992, Milisits et al. 2000).

In this experiment, rabbits were slaughtered at three different ages and in five body weight categories within each age group. The design of the experiment permitted the examination of the effects exerted by age and body weight on the carcass traits. The objective of this experiment was to study the effect of age and body weight on the carcass traits as well as on the chemical composition of meat on hind leg (HL) and on m. Longissimus dorsi (MLD) both separately and in combination.

\section{Materials and methods}

The experiment was carried out at the rabbit farm of the University of Kaposvár in Pannon White growing rabbits. The rabbits were reared in the conventional way and weaned at 35 days of age. After weaning, they were reared in fattening cages made of wire mesh until slaughtering (2-3 rabbits per cage). The rabbit house had $15-16^{\circ} \mathrm{C}$ average temperature, a $16 \mathrm{~L}: 8 \mathrm{D}$ lighting regime and overpressure ventilation. The rabbits were fed a commercial diet (energy: $10.3 \mathrm{DE} \mathrm{MJ} / \mathrm{kg}$, crude protein: $16 \%$, ether extract: $2.5 \%$, crude fibre: $15.5 \%$ ) ad libitum. Drinking water was available ad libitum from nipple drinkers. 


\section{Experimental design}

Three, randomly selected groups of does were mated with an interval of 10 days, thus the kits were born at different times. Rabbits - independently of their gender - belonging to the three age groups ( $n=238$ ) were slaughtered on the same day (so all of the animals were examined at the same time). Thus they were 74,84 and 94 days old, with the average body weight of $2.53,2.84$ and $3.15 \mathrm{~kg}$ respectively, at the time of slaughtering. Within each age group, rabbits were slaughtered at a body weight 0.3 and $0.6 \mathrm{~kg}$ more and less than the average weight, respectively. In this way the weight difference between two neighbouring weight and age groups was equally $0.3 \mathrm{~kg}$. This design enabled the separate examination of age and body weight on the carcass traits. The numbers of rabbits in the different experimental groups are shown in Table 1.

Table 1

Number of rabbits in the different age groups and body weight categories

\begin{tabular}{cccccccc}
\hline Age, days & \multicolumn{7}{c}{ Body weight categories } \\
& I & II & III & IV & V & VI & VII \\
\hline 74 & $4(4)$ & $14(10)$ & $21(10)$ & $19(10)$ & $9(9)$ & - & - \\
84 & - & $5(5)$ & $20(10)$ & $27(10)$ & $21(10)$ & $7(7)$ & - \\
94 & - & - & $11(10)$ & $19(10)$ & $31(10)$ & $19(10)$ & $11(10)$ \\
\hline
\end{tabular}

Body weight categories I: $1.86-2.05 \mathrm{~kg}, \quad$ II: $2.15-2.35 \mathrm{~kg}, \quad$ III: $2.49-2.63 \mathrm{~kg}, \quad$ IV: $2.78-2.92 \mathrm{~kg}, \quad$ V: $3.09-3.25 \mathrm{~kg}, \quad$ VI: $3.35-$ $3.52 \mathrm{~kg}$, VIl: $3.65-3.84 \mathrm{~kg}$, in brackets: number of meat samples

\section{Slaughtering and dissection procedure}

The rabbits were slaughtered at the slaughterhouse of Olivia Ltd., located at a distance of $200 \mathrm{~km}$ from the farm. They were weighed after removal from the cage and immediately before slaughter (after 24-hour fasting including the time of transport). After electric stunning, the rabbits were bled then the skin, the gastrointestinal tract and the distal part of legs were removed. At the end of the slaughtering line the hot carcasses (with the head, heart, lungs, liver, kidneys and fat depots) were weighed, then hung on a rack and chilled at $3^{\circ} \mathrm{C}$ for $24 \mathrm{~h}$. Then the chilled carcass was weighed again (its temperature was approx. $5^{\circ} \mathrm{C}$ ).

The carcasses were dissected according to the method described by Blasco \& Ouhayoun (1996). The head was separated from the carcass and then the liver, the kidneys and the perirenal fat were removed. The carcass was cut between the last thoracic and the first lumbar vertebrae and between the 6th and 7th lumbar vertebrae (fore, intermediate and hind parts). From the intermediate part (between the last thoracic and the first lumbar vertebrae) the $m$. Longissimus dorsi was removed, then the hind legs were deboned (hind leg meat $-\mathrm{HL}$ ). Reference carcass means the weight of chilled carcass without head, heart, lungs, liver and kidneys, but with fat depots. Dressing out percentage was calculated as the ratio of chilled carcass to liveweight before slaughter.

\section{Chemical composition of meat}

The meat samples (left part of the MLD and the left $\mathrm{HL}$ ) were stored at $-20^{\circ} \mathrm{C}$ until chemical analysis. As far as possible, 10 minced and homogenised HL and MLD samples were analysed 
from each group. Naturally, from groups comprising fewer than 10 animals all samples were analysed (Table 1).

Moisture of the meat samples was determined by the HS ISO 1442 (2000) method of drying to constant weight, the crude protein content by the HS ISO 937 (2002) method using KJEL-FOSS fast nitrogen meter, the crude fat content by the HS ISO 1443 (2002) method with Soxhlet extraction after hydrochloric acid digestion, and the crude ash content by HS ISO 936 (2000) method of ashing the samples at $550^{\circ} \mathrm{C}$ for $3 \mathrm{~h}$. The methods of the Hungarian Standards (HS) are similar to that of used in the EU.

\section{Statistical methods}

For the separated evaluation of the two factors (age or body weight) data of each age group and body weight category were analysed separately. This permitted to involve groups of rabbits being of younger age and lower body weight and of older age and heavier weight into the analysis. In this case one-way analysis of variance was used according to the following models:

$$
Y_{i j}=\mu+A_{i}+e_{i j}
$$

where $\mu$ is the population mean, $A_{i}$ is the effect of age $(i=1-3)$ and $e_{i j}$ is the error.

$$
Y_{i j}=\mu+B_{i}+e_{i j}
$$

where $\mu$ is the population mean, $B_{i}$ is the effect of body weight $(i=1-5)$ and $e_{i j}$ is the error.

The effect of gender was not taken into consider in the statistical analysis. The experimental data were processed by SAS programme package 9.1 (SAS 2001), LS mean was used.

\section{Results}

\section{Carcass traits}

Dressing out percentage increased with the increase of age in all body weight categories, however, the differences were significant only comparing the 74 days rabbits with other age group (between 74 and 84 days in the body weight categories of III., IV. and V. the increase was $2.9 ; 1.2$ and $2.2 \%$; resp.; $P<0.05$; Table 2). With the increase of body weight (within a given age category) the dressing out percentage improved, although the difference was significant only at 74 days (between the I. and IV. body weight categories it was $3.3 \%$; $P<0.0$; Table 2).

The effect of age on the ratio of the fore part of the carcass depended on the body weight: between 74 and 94 days of age in the body weight categories of III. and IV. the decrease was $2.5(P<0.05)$ and $1.5 \%(P<0.05)$ resp., while in the V. body weight category no difference was found (Table 2). The ratio of the fore part increased in heavier rabbits at 94 days of age (between III. and VII. body weight categories it was $2 \% ; P<0.05$ ), however, at 84 days of age significant difference was found in only one case, while at 74 days of age no any change was found (Table 2).

The ratio of the intermediate part of the carcass was not affected by age but it increased in rabbits of higher body weight, however, significant $(P<0.05)$ difference was found only between 74 and 94 days of age (Table 2). 
Table 2

Effects of age and body weight on the carcass traits of rabbits

\begin{tabular}{|c|c|c|c|c|c|c|c|}
\hline \multirow[t]{2}{*}{ Age, da) } & \multicolumn{7}{|c|}{ Body weight categories } \\
\hline & 1 & II & III & IV & V & VI & VII \\
\hline \multicolumn{8}{|c|}{ Liveweight at slaughter, g (total SEM: 7.27) } \\
\hline 74 & $1807^{\mathrm{A}}$ & $2097^{B}$ & $2348^{c}$ & $2646^{\mathrm{D}}$ & $2921^{\mathrm{E}}$ & - & - \\
\hline 84 & - & $2130^{A}$ & $2381^{B}$ & $2643^{c}$ & $2912^{D}$ & $3183^{E}$ & - \\
\hline 94 & - & - & $2390^{A}$ & $2651^{B}$ & $2932^{C}$ & $3215^{D}$ & $3497^{\mathrm{E}}$ \\
\hline \multicolumn{8}{|c|}{ Dressing out percentage, \% (total SEM: 0.26 ) } \\
\hline 74 & $56.4^{\mathrm{A}}$ & $56.8^{\mathrm{Aa}}$ & $57.8^{\mathrm{ABa}}$ & $59.7^{\text {ca }}$ & $58.7^{\mathrm{BCa}}$ & - & - \\
\hline 84 & - & $59.9^{b}$ & $60.7^{\mathrm{b}}$ & $60.9^{b}$ & $60.9^{b}$ & 60.9 & - \\
\hline 94 & - & - & $60.2^{\mathrm{a}}$ & $61.1^{\mathrm{b}}$ & $60.6^{b}$ & 61.3 & 60.5 \\
\hline \multicolumn{8}{|c|}{ Fore part to reference carcass ratio, \% (total SEM: 0.21 ) } \\
\hline 74 & $37.7^{\mathrm{AB}}$ & $38.0^{\mathrm{B}}$ & $38.1^{\mathrm{Bb}}$ & $37.8^{\mathrm{ABb}}$ & $36.1^{\mathrm{A}}$ & - & - \\
\hline 84 & - & $36.1^{A B}$ & $36.3^{\mathrm{Aa}}$ & $36.1^{\mathrm{Aa}}$ & $37.3^{B}$ & $36.6^{A B}$ & - \\
\hline 94 & - & - & $35.6^{\mathrm{Aa}}$ & $36.3^{\mathrm{ABa}}$ & $36.7^{B C}$ & $37.1^{c}$ & $37.6^{\mathrm{D}}$ \\
\hline \multicolumn{8}{|c|}{ Intermediate part to reference carcass ratio, \% (total SEM: 0.26 ) } \\
\hline 74 & $22.0^{A B}$ & $21.8^{\mathrm{Aa}}$ & $22.4^{\mathrm{Aa}}$ & $23.8^{\mathrm{BC}}$ & $24.6^{C}$ & - & - \\
\hline 84 & - & $23.8^{b}$ & $23.8^{\mathrm{b}}$ & 24.8 & 24.0 & 25.1 & - \\
\hline 94 & - & $23.6^{\text {Aab }}$ & $23.7^{A}$ & $24.0^{A}$ & $24.1^{A B}$ & $24.9^{\mathrm{B}}$ & \\
\hline \multicolumn{8}{|c|}{ Hind part to reference carcass ratio, \% (total SEM: 0.21 ) } \\
\hline 74 & $39.5^{c}$ & $39.0^{C}$ & $38.1^{\mathrm{BCa}}$ & $36.4^{\mathrm{Aa}}$ & $37.2^{\mathrm{ABab}}$ & - & - \\
\hline 84 & - & $39.1^{c}$ & $38.8^{\mathrm{Ca}}$ & $37.5^{\mathrm{Bb}}$ & $36.8^{\mathrm{ABa}}$ & $36.1^{\mathrm{A}}$ & - \\
\hline 94 & - & - & $39.9^{\mathrm{Eb}}$ & $38.8^{\mathrm{Dc}}$ & $37.8^{\mathrm{cb}}$ & $37.0^{\mathrm{B}}$ & $35.2^{\mathrm{A}}$ \\
\hline \multicolumn{8}{|c|}{ M. Iongissimus dorsi to reference carcass ratio, \% (total SEM: 0.13 ) } \\
\hline 74 & $7.41^{\mathrm{A}}$ & $8.00^{A B}$ & $8.43^{\mathrm{Ba}}$ & $8.58^{B}$ & $8.30^{A B}$ & - & - \\
\hline 84 & - & 8.73 & $9.05^{\mathrm{b}}$ & 9.08 & 8.59 & 9.27 & - \\
\hline 94 & - & - & $9.06^{\mathrm{ab}}$ & 8.95 & 8.75 & 9.13 & 9.13 \\
\hline \multicolumn{8}{|c|}{ Hind leg meat to reference carcass ratio, \% (total SEM: 0.18 ) } \\
\hline 74 & 25.5 & 25.5 & $25.6^{\mathrm{a}}$ & $25.0^{\mathrm{a}}$ & 25.5 & - & - \\
\hline 84 & - & 24.6 & $26.0^{\mathrm{a}}$ & $25.7^{\mathrm{a}}$ & 25.9 & 25.0 & - \\
\hline 94 & - & - & $27.1^{\mathrm{cb}}$ & $26.6^{B C b}$ & $26.0^{B C}$ & $25.9^{\mathrm{B}}$ & $23.7^{\mathrm{A}}$ \\
\hline \multicolumn{8}{|c|}{ Perirenal fat to reference carcass ratio, \% (total SEM:0.08) } \\
\hline 74 & $0.83^{A}$ & $1.27^{\mathrm{A}}$ & $1.41^{\mathrm{Ab}}$ & $1.97^{\mathrm{BC}}$ & $2.09^{\mathrm{Bb}}$ & - & - \\
\hline 84 & - & $1.00^{A}$ & $1.17^{\text {Aab }}$ & $1.65^{\mathrm{Bb}}$ & $1.82^{\mathrm{BCab}}$ & $2.23^{C}$ & - \\
\hline 94 & - & - & $0.89^{\mathrm{Aa}}$ & $1.23^{\mathrm{Aa}}$ & $1.63^{\mathrm{Ba}}$ & $1.86^{B C}$ & $2.26^{\mathrm{c}}$ \\
\hline
\end{tabular}

Body weight categories I: $1.86-2.05 \mathrm{~kg}, \quad$ II: $2.15-2.35 \mathrm{~kg}, \quad$ III: $2.49-2.63 \mathrm{~kg}, \quad$ IV: $2.78-2.92 \mathrm{~kg}, \quad$ V: $3.09-3.25 \mathrm{~kg}, \quad$ VI: $3.35-$ $3.52 \mathrm{~kg}$, VIl: $3.65-3.84 \mathrm{~kg}$, ${ }^{\mathrm{a}, \mathrm{b}}$ different subscripts mark significant difference $(P \leq 0.05)$ between the age groups, $A, B, C, D, E$ different superscripts mark significant difference $(P \leq 0.05)$ between the body weight categories

The ratio of the hind part of the carcass increased in older animals (between 74 and 94 days of age in the III., IV. and V. body weight categories the increase was $1.8 \% / P<0.05 /, 2.4 \%$ / $P<0.05 /$ and $0.6 \% / \mathrm{NS} /$, resp., Table 2). While it decreased in rabbits of higher body weight, and this decrease was higher in older rabbits (between the lightest and the heaviest group at 74,84 and 94 days of age it was $2.3,3.0$ and $4.7 \%$, resp.).

The ratio of MLD increased in older animals, but this was significant only in the III. body weight category (between 74 and 94 days of age the increase was $0.63 \%$, Table 2). With the increased body weight the ratio of MLD increased only in 74 days of age (between the I. and VI. body weight categories it was $1.17 \%$, Table 2). 
The ratio of $\mathrm{HL}$ increased in older animals, but this was significant in lower body weights (between 74 and 94 days of age in the III. IV. and V. body weight categories the increase was $1.5 \% / P<0.05 /, 1.6 \% / P<0.05 /$ and $0.5 \% / N S /$, Table 2). At 74 and 84 days of age no change was found in the ratio of $\mathrm{HL}$, while in 94 days old rabbits significant decrease was found between the lightest and the heaviest body weight categories (3.4\%, Table 2 ).

The ratio of the perirenal fat to reference carcass significantly decreased with age in all body weight categories (between 74 and 94 days of age in the III., IV. and V. body weight categories it was $0.52,0.74$, and $0.46 \%$, resp., $P<0.05$, Table 2 ), but it significantly increased in rabbits of higher body weight (between the lightest and the heaviest rabbits at 74, 84 and 94 days of age the increase was $1.26,1.23$ and $1.37 \%$, resp., Table 2 ).

\section{Meat composition}

With the advancement of age the moisture content of the HL increased (between 74 and 94 days of age in the III., IV. and V. body weight categories it was $0.4 / N S /, 0.9 / P<0.05 /$ and $1.5 \% / P<0.05 /$, resp.), while that of the MLD did not change (Table 3 ). With the increase of body weight, moisture content decreased in both the HL and in the MLD (between the lightest and the heaviest rabbits at 74, 84 and 94 days of age in the $\mathrm{HL}$ the decrease was: 3.6, 1.8 and $1.6 \%, P<0.05$, resp.; in the MLD it was $0.5,0.5$ and $0.8 \%, P<0.05$, resp. Table 3 ).

The fat content of both the HL and the MLD decreased in older animals (between 74 and 94 days of age in the III. IV. and V. body weight categories in the HL the decrease was 1.03 /NS/, $1.48 / P<0.05 /$ and $2.25 \% / P<0.05 /$, resp.; in the MLD it was $0.03 / N S /, 0.28 / P<0.05 /$ and $0.31 \% / P<0.05 /$, resp. Table 3 ). While it increased in rabbits of higher body weight (between the lightest and the heaviest rabbits at 74, 84 and 94 days of age in the HL the increase was 4.07, 2.2 and $1.91 \%$, resp., $P<0.05$; in the MLD it was $0.28,0.62$ and $0.51 \%$, resp., $P<0.05$, Table 3 ).

The crude protein content in the $\mathrm{HL}$, significantly increased in all body weight categories $(P<0.05)$ (except in $3.35-3.52 \mathrm{~kg})$ in comparison with the 74 -day-old rabbits, however, these differences were random (Table 3). On the contrary, the crude protein content of the MLD was influenced significantly by the age in the II., IV. and VI. body weight categories (Table 3). However, with the increase of body weight a statistically significant increase in the crude protein content of the MLD was found in the 74 and 94-day-old rabbits in several cases (Table 3). 
Table 3

Separated effects of age and body weight on the chemical composition of rabbit meat

\begin{tabular}{|c|c|c|c|c|c|c|c|}
\hline \multirow[t]{2}{*}{ Age, days } & \multicolumn{7}{|c|}{ Body weight categories } \\
\hline & 1 & II & III & IV & V & VI & VII \\
\hline \multicolumn{8}{|c|}{ M. longissimus dorsi } \\
\hline \multicolumn{8}{|c|}{ Moisture, \% (Total SEM: 0.100) } \\
\hline 74 & $74.6^{\mathrm{ABC}}$ & $75.2^{\mathrm{C}}$ & $74.7^{\mathrm{B}}$ & $74.6^{\mathrm{AB}}$ & $74.1^{\mathrm{Aa}}$ & - & - \\
\hline 84 & - & $74.9^{A B}$ & $74.9^{\mathrm{B}}$ & $74.4^{\mathrm{A}}$ & $74.7^{\mathrm{ABb}}$ & $74.4^{\mathrm{A}}$ & - \\
\hline 94 & - & - & $75.0^{c}$ & $74.7^{\mathrm{BC}}$ & $74.5^{\mathrm{ABab}}$ & $74.2^{\mathrm{A}}$ & $74.2^{\mathrm{A}}$ \\
\hline \multicolumn{8}{|c|}{ Crude protein, \% (Total SEM: 0.084) } \\
\hline 74 & $23.3^{B}$ & $22.7^{\mathrm{Aa}}$ & $23.4^{\mathrm{B}}$ & $23.2^{\mathrm{Ba}}$ & $23.5^{\mathrm{B}}$ & - & - \\
\hline 84 & - & $23.4^{\mathrm{b}}$ & 23.4 & $23.6^{\mathrm{b}}$ & 23.4 & $23.2^{\mathrm{a}}$ & - \\
\hline 94 & - & - & $23.0^{\mathrm{A}}$ & $23.3^{\mathrm{ABab}}$ & $23.5^{\mathrm{BC}}$ & $23.8^{\mathrm{Cb}}$ & $23.2^{A B}$ \\
\hline \multicolumn{8}{|c|}{ Ether extract, \% (Total SEM: 0.045) } \\
\hline 74 & $0.87^{A B}$ & $0.80^{\mathrm{A}}$ & $0.79^{\mathrm{A}}$ & $0.92^{\mathrm{ABb}}$ & $1.15^{\mathrm{Bb}}$ & - & - \\
\hline 84 & - & $0.58^{A B}$ & $0.53^{\mathrm{A}}$ & $0.81^{\mathrm{Cab}}$ & $0.76^{\mathrm{BCa}}$ & $1.20^{\mathrm{Db}}$ & - \\
\hline 94 & - & - & $0.76^{\mathrm{A}}$ & $0.64^{\mathrm{Aa}}$ & $0.84^{\mathrm{Aa}}$ & $0.79^{\mathrm{Aa}}$ & $1.27^{\mathrm{B}}$ \\
\hline \multicolumn{8}{|c|}{ Ash, \% (Total SEM: 0.017) } \\
\hline 74 & $1.31^{A B}$ & $1.31^{\mathrm{ABb}}$ & $1.27^{\mathrm{A}}$ & $1.35^{\text {Bab }}$ & $1.33^{\mathrm{ABb}}$ & - & - \\
\hline 84 & - & $1.25^{\mathrm{Aa}}$ & $1.27^{A B}$ & $1.29^{\mathrm{Ba}}$ & $1.25^{\mathrm{Aa}}$ & $1.25^{\mathrm{Aa}}$ & - \\
\hline 94 & - & - & $1.32^{A B}$ & $1.42^{\mathrm{Bb}}$ & $1.29^{\text {Aab }}$ & $1.33^{\mathrm{ABb}}$ & $1.41^{\mathrm{B}}$ \\
\hline \multicolumn{8}{|c|}{ Hind leg meat } \\
\hline \multicolumn{8}{|c|}{ Moisture, \% (Total SEM: 0.196) } \\
\hline 74 & $76.1^{\mathrm{D}}$ & $74.9^{\mathrm{CD}}$ & $74.3^{B C}$ & $73.6^{\mathrm{Ba}}$ & $72.5^{\mathrm{Aa}}$ & - & - \\
\hline 84 & - & $74.5^{\mathrm{BC}}$ & $74.9^{c}$ & $74.0^{\mathrm{BCab}}$ & $73.4^{\mathrm{ABab}}$ & $72.7^{\mathrm{Aa}}$ & - \\
\hline 94 & - & - & $74.7^{c}$ & $74.5^{\mathrm{BCb}}$ & $74.0^{\mathrm{BCb}}$ & $73.8^{\mathrm{ABb}}$ & $73.1^{\mathrm{A}}$ \\
\hline \multicolumn{8}{|c|}{ Crude protein, \% (Total SEM: 0.071) } \\
\hline 74 & $21.2^{\mathrm{B}}$ & $20.7^{\text {Аa }}$ & $20.8^{\mathrm{ABa}}$ & $20.7^{\mathrm{Aa}}$ & $20.7^{\mathrm{Aa}}$ & - & - \\
\hline 84 & - & $21.7^{\mathrm{Bb}}$ & $21.1^{\text {Aab }}$ & $21.5^{\mathrm{Bb}}$ & $21.5^{\mathrm{Bb}}$ & $21.2^{\mathrm{AB}}$ & - \\
\hline 94 & - & - & $21.5^{\mathrm{Bb}}$ & $21.3^{\mathrm{ABb}}$ & $21.4^{\mathrm{ABb}}$ & $21.3^{A B}$ & $21.2^{\mathrm{A}}$ \\
\hline \multicolumn{8}{|c|}{ Ether extract, \% (Total SEM: 0.181) } \\
\hline 74 & $1.51^{\mathrm{A}}$ & $3.21^{\mathrm{B}}$ & $3.71^{\mathrm{BC}}$ & $4.50^{\mathrm{cb}}$ & $5.58^{\mathrm{Db}}$ & - & - \\
\hline 84 & - & $2.71^{\mathrm{A}}$ & $2.85^{\mathrm{A}}$ & $3.28^{\mathrm{ABa}}$ & $3.92^{\mathrm{Ba}}$ & $4.91^{\mathrm{cb}}$ & - \\
\hline 94 & - & - & $2.68^{\mathrm{A}}$ & $3.02^{\mathrm{Aa}}$ & $3.33^{\mathrm{ABa}}$ & $3.80^{\mathrm{Ba}}$ & $4.59^{\mathrm{C}}$ \\
\hline \multicolumn{8}{|c|}{ Ash, \% (Total SEM: 0.017) } \\
\hline 74 & $1.23^{\mathrm{AB}}$ & $1.28^{\mathrm{Bb}}$ & $1.22^{\mathrm{A}}$ & $1.21^{\mathrm{A}}$ & $1.25^{\mathrm{AB}}$ & - & - \\
\hline 84 & - & $1.18^{\mathrm{Aa}}$ & $1.24^{A B}$ & $1.23^{A B}$ & $1.26^{\mathrm{AB}}$ & $1.30^{\mathrm{Bb}}$ & - \\
\hline 94 & - & - & $1.18^{A B}$ & $1.23^{\mathrm{AB}}$ & $1.26^{\mathrm{B}}$ & $1.19^{\mathrm{ABa}}$ & $1.16^{\mathrm{A}}$ \\
\hline
\end{tabular}

Body weight categories I: $1.86-2.05 \mathrm{~kg}, \quad$ II: $2.15-2.35 \mathrm{~kg}, \quad$ III: $2.49-2.63 \mathrm{~kg}, \quad$ IV: $2.78-2.92 \mathrm{~kg}, \quad$ V: $3.09-3.25 \mathrm{~kg}, \quad$ VI: $3.35-3.52 \mathrm{~kg}$, VII: $3.65-3.84 \mathrm{~kg}$, ${ }^{a, b}$ different letters denote significant difference $(P \leq 0.05)$ between the age groups, $A, B, C, D$ different letters denote significant difference $(P \leq 0.05)$ between the body weight categories

\section{Discussion}

\section{Carcass traits}

Similarly to the present results, several authors observed that the improvement of the dressing out percentage was more expressed at a younger age (Deltoro \& López 1986, Lebas et al. 2001, Szendrő et al. 2002) or at a lower body weight (Szendrő et al. 1998) than in older and heavier rabbits. Studying rabbits of identical body weight $(2.45 \mathrm{~kg})$, Cabanes-Roiron \& Ouhayoun (1994) found a higher dressing out percentage in older rabbits. Milisits et al. (2000) 
also obtained a higher dressing out percentage in heavier and older rabbits. When rabbits of different age were slaughtered at the same body weight, Roiron et al. (1992) observed a significant effect of the body weight; however, they could not statistically confirm the higher dressing out percentage found in older rabbits. Since at an older age or in higher body weight the influence of body weight or age decreases or disappears, the effect of the two factors should be treated with caution. Gondret et al. (2004) compared two rabbit lines divergently selected for body weight at 63 days during 6 generations and found $1.12 \%$ higher $(P<0.05)$ dressing out percentage in line selected for high body weight at 63 days of age.

According to the findings of Deltoro \& López (1986) and Szendrö et al. (2002), the ratio of the fore part of the carcass decreases markedly especially at a very young age (up to 8-10 weeks of age), while in older rabbits either a small increase or a further (non-significant) decrease has been observed. Petersen et al. (1988) reported only a minor change with the age. No change in the ratio of the fore part within the carcass has been reported by Szendrö et al. (1998) and by Rao et al. (1978). But in these experiments the older rabbits were heavier as well. Cabanes-Roiron \& Ouhayoun (1994) did not find differences in the ratio of the fore part between rabbits of the same body weight but different age. Milisits et al. (2000) could not detect a significant effect of either age or body weight. Since the fore part is the most bony part of the carcass, its growth and the change of its ratio within the carcass may be associated with the growth rate of the bone tissue. Thus, at a higher body weight the age exerts a less pronounced effect on it; in other words, if the animal weighs more at a younger age, the growth status of its skeleton is closer to the status typical of adult animals.

Numerous data of the literature demonstrate that the ratio of the intermediate part of the carcass increases in older rabbits (Deltoro \& López 1986, Petersen et al. 1988, Szendrő et al. 2002). According to the present experimental results this change can be explained by the increase of body weight rather than by the advancement of age. This assumption is confirmed by the experimental findings of Cabanes-Roiron \& Ouhayoun (1994), who could not detect the effect of age in rabbits of identical body weight, as well as by the results of Milisits et al. (2000), who compared groups of rabbits slaughtered at the same age but at different body weight or at the same body weight but at different age and established that only the body weight exerted a significant effect on the ratio of the intermediate part of the carcass.

Evaluating the separated effects of age and body weight, on ratio of hind part Milisits et al. (2000) reported similar tendency to our study, although the change was significant only in a single case because of the low number of animals studied. In rabbits of identical body weight, Cabanes-Roiron \& Ouhayoun (1994) observed a significant increase in the hind part ratio in older rabbits. According to the results of Deltoro \& López (1986) and Szendrö et al. (2002), the ratio of the hind part and of the hind legs within the carcass increased more at a younger age than in older rabbits. However, other authors (Rao et al. 1978, Petersen et al. 1988) did not observe substantial changes in that respect. Although the effect of body weight was detectable, the decrease was not significant in rabbits weighing more than $2.2 \mathrm{~kg}$ (Szendrö et al. 1998). These age and body weight related changes are probably associated with the stage of maturity of the animal as compared to the adult body weight at the given time of examination, i.e. they depend on how far muscle development has progressed towards its completion. 
According to the results of Rudolph \& Fischer (1979), between 86 and 100 days of age no significant difference was found in the $m$. Longissimus dorsi to carcass ratio. However, in case of a greater age difference (between 46 and 95 days of age) an increase was observed (Petersen et al. 1988), but scarcely any change took place between 88 and 95 days of age.

According to the data of the literature, in case of a combined effect of the two factors the weight of hind leg meat increases with age (Parigi-Bini et al. 1992). This increase is more expressed at a younger age. The muscle development shows an increasing rate between birth and 84 days of age and its rate decreases after 84 days of age (Rudolph et al. 1986). This may explain the changes found in the present experiment, according to which the weight of hind leg meat increased by $40 \mathrm{~g}$ between 74 and 84 days of age and only by half as much ( $20 \mathrm{~g}$ ) between 84 and 94 days of age.

Data of the literature indicate that in older rabbits the weight (Petersen et al. 1988, Szendrő et al. 2002) and the ratio of perirenal fat (Parigi-Bini et al. 1992, Lebas et al. 2001, Szendrő et al. 2002) increase due to the mixed effects of age and body weight. Similar observations were made when the ratio of perirenal fat was studied on the basis of body weight changes (Ristic et al. 1988, Maertens \& De Groote 1992). When the effects of the two factors were separated, it was found that the ratio of perirenal fat was higher in rabbits of the same age but of higher body weight, while the effect of age was not demonstrable in rabbits of the same body weight (Roiron et al. 1992). Milisits et al. (2000) measured perirenal fat weights increasing with the body weight but significantly decreasing with age. Actually, the effect of age and that of body weight are not opposite. At a given age, heavier rabbits tend to grow faster and, partly because of their higher feed intake, grow fat more rapidly. When comparing animals of identical body weight, older rabbits grow slower and, thus, have a lower chance to become fatty than rabbits reach the same body weight at a younger age.

With the advancement of age Rao et al. (1978) and Szendrö et al. (2002) reported a pronounced decrease in the liver to liveweight ratio. In these experiments the body weight of rabbits increased with their age. Studying the effect of the body weight, Maertens \& De Groote (1992) found a slight decrease in the liver weight to body weight ratio with the increase of body weight. The independent effect of age was demonstrated by the experiment of Cabanes-Roiron \& Ouhayoun (1994) who studied rabbits of the same weight to demonstrate that the relative weight of the liver was significantly lower in 70 days old rabbits than at 62 days of age. These results support our assumption that age exerts a more pronounced effect on the liver weight to body weight ratio than does the body weight.

Studies of the separated effects of the two factors often throw a new light upon changes of the carcass traits. It has been shown that the intensity of the effect may change with age or with the increase of the body weight. The ratio of the fore, intermediate and hind part varies within the carcass. With the advancement of age the ratio of the fore part decreases, that of the intermediate part remains unchanged, whereas the ratio of the hind part increases. In rabbits of higher body weight the ratio of the fore and intermediate parts tends to increase while that of the hind part distinctly decreases. The variable rate of meat incorporation in the different body parts is demonstrated by changes in the ratio of $m$. Longissimus dorsi and hind leg meat within the carcass. Older (more mature) rabbits are characterised by higher meat incorporation, while the effect of body weight is not clear and may vary by body parts. 
Age and body weight seems to exert an opposite influence on perirenal fat weight and its ratio within the carcass. This contradiction is, however, only virtual, as it is the rate of growth that determines the rate of fat deposition in both cases. If a rabbit has higher body weight at a given age or if it reaches a given body weight at a younger age, then it will eat more, grow faster and, naturally, fatten at a faster rate.

\section{Meat composition}

The present results are partially opposite to those reported in the literature. Studying the effect of age in rabbits Petersen et al. (1988), Parigi-Bini et al. (1992), Dalle Zotte et al. (1996) and Cavani et al. (2000) found that the moisture of meat decreased with the advancement of age. In studies investigating the effect exerted by body weight, Ristic et al. (1988) observed a tendency of slight increase while Maertens \& De Groote (1992) and Szendrő et al. (1998) reported a significant decrease in the moisture of meat between a body weight of 2.6 and $3.0 \mathrm{~kg}$. However, it should be mentioned that in the experiments cited above the body weight increased with age and, conversely, age increased with the body weight. In rabbits of the same age but different body weight Grashorn et al. (1996) and Petracci et al. (1999) did not find a significant difference in the moisture of meat. At the same time, Milisits et al. (2000) reported changes that are fully consistent with the present findings. Especially in the $\mathrm{HL}$, moisture content tended to increase with the advancement of age and it tended to decrease with increasing body weight. Therefore, on the basis of the results obtained in this study it can be established that the moisture of the $\mathrm{HL}$ is influenced both by age and body weight. However, these two factors have an opposite effect, as moisture increases with age and decreases with increasing body weight. A similar tendency can be observed in the moisture of the MLD, but the effect of age is not statistically significant and the moisture of this meat only slightly decreases with the increasing body weight. However, it must be stated that this opposite effect of age and body weight is only ostensible, as in both cases it is the growth rate that determines the changes. Namely, rabbits having a higher body weight at a given age have a higher weight gain in the same way as those rabbits which attain a higher body weight at a younger age. As will be discussed later, higher growth rate affects the fat content of meat, and fat is incorporated into the cells replacing the water.

Studying the effect of age on the crude protein content of meat, Rao et al. (1978) and Parigi-Bini et al. (1992) did not find significant changes. In contrast, Cavani et al. (2000) obtained a higher value in older while Dalle Zotte et al. (1996) in younger rabbits. Maertens \& De Groote (1992) and Szendrő et al. (1998) found no correlation between the body weight and the protein content of meat. Ristic et al. (1988) obtained a higher crude protein content in the meat of rabbits with a lower body weight in most cases. Studying rabbits of the same age, Petracci et al. (1999) could not detect any correlation between body weight and crude protein of the MLD. Evaluation of the results obtained in our study in combination with those presented in the literature does not allow us to draw clear conclusions. According to the results of the present experiment the protein content of HL was significantly higher in 84-day-old and 94-day-old rabbits as compared to the 74-day-old animals, irrespective of the body weight. At the same time, in the MLD there was no connection between the age and the protein content of muscles, and the effect of body weight was not clearly evident either. 
In their studies on the fat content of meat Petersen et al. (1988), Parigi-Bini et al. (1992), Dalle Zotte et al. (1996) and Cavani et al. (2000) observed values that rose significantly with the advancement of age. But in these studies the change of age was parallel with that of body weight. Szendrő et al. (1998) found that the fat content of the meat of rabbits of different body weight (and also of different age) increased parallel to the body weight, while that of the MLD did not change significantly. Maertens \& De Groote (1992) also did not find significant changes in the fat content of the whole carcass. Studying rabbits of the same age, Grashorn et al. (1996) and Petracci et al. (1999) could not confirm the effect of body weight on carcass fat content. In contrast, the results obtained in the present study clearly demonstrate that within a given age group the HL and MLD of rabbits of higher body weight have higher fat content, while within groups of the same body weight the fat content of meat is lower in older animals. As it has already been pointed out for the moisture, the opposite role of age and body weight is only ostensible. High body weight gain is conditional upon a higher feed consumption, while rabbits with a voracious appetite tend to become obese more easily. This is demonstrated by the results of Cabanes-Roiron \& Ouhayoun (1994), who compared 62 days old and 73 days old rabbits equally weighing $2.45 \mathrm{~kg}$, and found that the amount of perirenal fat was lower in the latter group (2.1 vs. $1.9 \%)$. Similarly, studying rabbits of the same body weight Milisits et al. (2000) measured significantly less perirenal fat in older animals.

According to data reported by Parigi-Bini et al. (1992) and Dalle Zotte et al. (1996) the ash content of the meat of older rabbits is significantly lower. At the same time, other authors (Ristic et al. 1988, Szendrő et al. 1998) also could not demonstrate an effect of body weight on meat crude ash content (in rabbits of different age). From the collective analysis of results obtained in our study and those reported in the literature it appears that the age or the body weight in itself does not exert an influence on the crude ash content of meat. However, if older rabbits also have higher body weight, the ash content of their muscles may be lower.

In conclusion, studies of the separated effects of the two factors often throw a new light upon changes of the carcass traits. Determination of the ideal slaughter age or body weight is complex, since it could depend on products. According to the present results dressing out percentage is improved by both the advancement of age and the increase of body weight. In the viewpoint of the intermediate part rabbits of higher body weight, while in case of the hind part older rabbits are the advantageous. Faster growth (higher body weight at a given age or given body weight at a younger age) results higher intramuscular fat content. The increase in the fat content of meat is not in contradiction with the consumer's demand on rabbit meat of low fat content. The fat content of the MLD scarcely differs from the $1 \%$, while that of the HL mostly varies between 2 and $5 \%$, which indicates that meat of older or heavier rabbits have excellent dietetic value.

\section{Acknowledgements}

The experiment was supported by the NKFP research project no. 4/034/2001, by the OTKA 83150 and the Bolyai János Research Grant BO/26/11/4. 


\section{References}

Blasco A, Ouhayoun J (1996) Harmonization of criteria and terminology in rabbit meat research. Revised proposal. World Rabbit Sci 4, 93-99

Cabanes-Roiron A, Ouhayoun J (1994) Precocity of the the rabbits' growth. Influence of slaughter age for the slaughter value and meat characteristics of rabbits slaughtered at the same live weight. 6èmes Journ. Rech. Cunicole, La Rochelle 2, 385-391 [in French]

Cavani C, Bianchi M, Lazzaroni C, Luzi F, Minelli G, Petracci M (2000) Influence of type of rearing, slaughtering age and sex on fattening rabbit: II. Meat quality. 7th World Rabbit Congr, Valencia, Spain, 567-572

Dalle Zotte A, Ouhayoun J, Parigi-Bini R, Xiccato G (1996) Effect of age, diet and sex on muscle energy metabolism and on related physicochemical traits in the rabbit. Meat Sci 43, 15-24

Dalle Zotte A (2002) Perception of rabbit meat quality and major factors influencing rabbit carcass and meat quality. Livest Prod Sci 75, 11-32

Deltoro J, López AM (1986) Development of commercial characteristics of rabbit carcasses during growth. Livest Prod Sci 15, 271-283

Gondret F, Combes S, Larzul C, Rochambeau HD (2005) The influence of divergent selection for body weight at 63 days of age in rabbits on muscle characteristics at a same age or at similar weight. Arch Tierz 48, Special Issue, 98-104

Grashorn MA, Zimmermann J, Bessei W (1996) Meat quality features of light and heavy types of New Zealand White rabbits. 6th World Rabbit Congr, Toulouse, France 3, 173-175

HS ISO 1442 (2000) Meat and meat products. Determination of moisture content (Reference method). Hungarian Standards Institution [in Hungarian]

HS ISO 1443 (2002) Meat and meat products. Determination of total fat content. Hungarian Standards Institution [in Hungarian]

HS ISO 936 (2000) Meat and meat products. Determination of total ash. Hungarian Standards Institution [in Hungarian]

HS ISO 937 (2002) Meat and meat products. Determination of nitrogen content (reference method). Hungarian Standards Institution [in Hungarian]

Lebas F, Retailleau B, Hurtaud J (2001) Evolution between 6 and 20 weeks of age of some slaughter and body composition traits in 2 rabbit lines. 9ème J Rech Cunicole, Paris, 55-58 [in French]

Maertens L, De Groote G (1992) Study of the influence of slaughter weight on carcass composition of broiler rabbits. Rev Agr 45, 59-68 [in Dutch]

Milisits G, Romvári R, Szendrő ZS, Masoero G, Bergoglio G (2000) The effect of age and weight on slaughter traits and meat composition of Pannon White growing rabbits. 7th World Rabbit Congr, Valencia, Spain, 629-636

Parigi-Bini R, Xiccato G, Cinetto M, Dalle Zotte A (1992) Effect of slaughter age and weight on carcass and meat quality of the commercial rabbit. J Appl Rabbit Res 15, 819-826

Petersen J, Schweicher I, Gerken M, Lammers HJ (1988) The age-related development of body composition of hybrid rabbits. Züchtungskunde 60, 72-84 [in German]

Petracci M, Capozzi F, Cavani C, Cremonini MA, Minelli G (1999) Influence of slaughter weight and sex on meat quality of rabbits slaughtered at the same age. Proc. 13th, ASPA Congr, Piacenza, Italy, 650-652

Rao DR, Chen CP, Sunki GR, Johnson WM (1978) Effect of weaning and slaughter ages on rabbit meat production. II. Carcass quality and composition. J Anim Sci 46, 578-583

Ristic M, Schloaut W, Lange K (1988) Influence of final fattening weight on the carcase value and meat quality of young rabbits. 4th World Rabbit Congr, Budapest, Hungary, 197-208

Roiron A, Ouhayoun J, Delmas D (1992) Effect of body weight and age on carcass and meat traits of rabbits. Cuniculture 19, 143-150 [in French] 
Rudolph W, Fischer W (1979) Carcass quality of broiler rabbits aged 86 and 100 days. Arch Tierz 22, 201-207 [in German]

Rudolph W, Sotto V, Dunker M (1986) Growth and carcass traits in New Zealand White Rabbits. Arch Tierz 29, 5-11

SAS (2001) SAS/STAT User's Guide, Version 9.1. Cary, NC, USA

Szendrő ZS, Kenessey Á, Metzger SZ, Radnai I, Biró-Németh E (2002) Change of the carcass value of Pannon White growing rabbits between 6 and 16 weeks of age. Állattenyésztés és Takarmányozás 51, 35-45 [in Hungarian]

Szendrő ZS, Radnai I, Biró-Németh E, Romvári R, Milisits G, Kenessey Á (1998) The effect of live weight on the carcass traits and the chemical composition of meat of Pannon White rabbits between 2.2 and $3.5 \mathrm{~kg}$. World Rabbit Sci 6, 243-249

Szendrő ZS (1989) Effect of age and body weight on the dressing out percentage of New Zealand White growing rabbits. Állattenyésztés és Takarmányozás 38, 47-53 [in Hungarian]

Received 10 March 2011, accepted 6 June 2011.

Corresponding author:

András Szabó

email: szan1125@freemail.hu

Faculty of Animal Science, University of Kaposvar, 7400 Kaposvar, Guba S. str. 40, Hungary 